Proteomics. 2018 March ; 18(5-6): e1700394. doi:10.1002/pmic.201700394.

\title{
The Human Eye Proteome Project: Updates on an Emerging Proteome
}

\author{
Dr. Meleha T. Ahmad, \\ Wilmer Eye Institute, Johns Hopkins University School of Medicine, Baltimore, MD, USA \\ Dr. Pingbo Zhang, \\ Wilmer Eye Institute, Johns Hopkins University School of Medicine, Baltimore, MD, USA \\ Dr. Craig Dufresne, \\ Thermo Fisher Scientific, West Palm Beach, FL, USA \\ Dr. Luigi Ferrucci, and \\ National Institute on Aging, National Institutes of Health, Baltimore, MD, USA \\ Prof. Richard D. Semba \\ Wilmer Eye Institute, Johns Hopkins University School of Medicine, Baltimore, MD, USA
}

\begin{abstract}
The human eye is a complex organ consisting of multiple compartments with unique and specialized properties that reflect their varied functions. Although there have been advancements in ocular imaging and therapeutics over the past decade, the pathogenesis of many common eye diseases remains poorly understood. Proteomics is an invaluable tool to gain insight into pathogenesis, diagnosis, and treatment of eye diseases. By 2013, when the Human Eye Proteome Project (also known as the EyeOme) was founded, there were 4842 nonredundant proteins identified in the human eye. Twenty-three recent papers on the human eye proteome were identified in PubMed searches. These papers were used to compile an updated resource of 9782 nonredundant proteins in the human eye. This updated catalogue sheds light on the molecular makeup of previously undescribed proteomes within the human eye, including optic nerve, sclera, iris, and ciliary body, while adding additional proteins to previously characterized proteomes such as aqueous humor, lens, vitreous, retina, and retinal pigment epithelium/choroid. Although considerable advances have been made to characterize the complete proteome of the human eye, additional high-quality data are needed to confirm and quantify previously discovered eye proteins in both health and disease.
\end{abstract}

\section{Keywords}

biomedicine; eye; proteome; mass spectrometry

Correspondence to: Richard D. Semba.

Conflict of Interest

Craig Dufresne is a full-time instructor at Thermo Fisher Scientific. The remaining authors have declared no conflicts of interest.

Supporting Information

Supporting Information is available from the Wiley Online Library or from the author. 


\section{Introduction}

Globally, there are an estimated 253 million people living with visual impairment, 36 million of whom are blind and 217 million of whom have moderate to severe visual impairment. ${ }^{[1]}$ Chronic eye diseases account for the majority of vision loss, with uncorrected refractive errors and unoperated cataract being the top two causes of visual impairment world-wide. Other important causes for visual impairment include age-related macular degeneration (AMD), glaucoma, diabetic retinopathy (DR), and to a lesser extent, trachoma and onchocerciasis. In 2010, the global health cost of visual impairment and blindness was an estimated $\$ 3.2$ trillion. ${ }^{[2]}$ Although it is widely quoted that $80 \%$ of blindness worldwide is preventable and treatable, increasing proportions of visual impairment are caused by chronic ocular diseases such as AMD or glaucoma, for which there is no effective prevention or cure. ${ }^{[3]}$ Improvement in the understanding of the molecular pathogenesis of common ocular diseases could assist in development of novel therapeutics and is attainable through proteomic study.

The eye is a unique organ composed of various tissues that work together to capture and focus light, converting it to the neural signals that are processed by the brain as visual images. Integral to this process are the tear film, cornea, conjunctiva, aqueous humor, iris, lens, vitreous humor, retina, retinal pigment epithelium and choroid, optic nerve and sclera, as well as surrounding tissues such as the lacrimal apparatus, extraocular muscle, orbit, and eyelids. To support these functions, each tissue within the eye must hold exclusive physical and biochemical properties. The cornea and lens must maintain their clarity; the ciliary body must relax and contract in response to visual stimuli; the lens must maintain dynamic ability to change shape; and the retina must convert light signals to electrical signals. The diverse and complex properties of each tissue within the human eye create a rich proteomic landscape that can now be characterized by modern advanced mass spectrometry instruments.

Proteomics provides an important tool to identify and quantify proteins, including their isoforms, variants and posttranslational modifications, in the compartments of the eye in both health and disease. Potential applications of proteomics include an improved understanding of the molecular underpinnings of common ocular diseases, identifications of biomarkers of disease for improved diagnostics and prognostics, and monitoring of treatment response. There is also the opportunity for development of new therapies and drug repurposing. ${ }^{[4]}$ For more easily accessible tissues, such as tears, aqueous humor or vitreous humor, better characterization of the proteome may allow disease prognostication on an individual level or better delivery of personalized medicine. ${ }^{[5]}$ The Human Eye Proteome Project (HEPP), an open initiative of the Human Proteome Organization (HUPO), aims to facilitate these goals by establishing standards for ocular proteome research and ultimately identifying and quantifying proteins in the human eye. The goal of this review is to provide an updated database of proteomic investigations of the human eye and to highlight recent findings since 2013. ${ }^{[6]}$ 


\section{Methods}

We identified 23 proteomic papers on the human eye published since our initial review of the EyeOme in 2013 with 27 compartment-specific datasets available in their supplementary files. Candidate papers were identified through PubMed searches that used the terms "proteome," "proteomics," "mass spectrometry" and "eye," "conjunctiva," "cornea," "tears," "aqueous," "iris," "ciliary body," "lens," "vitreous," "retina," "choroid," "retinal pigment epithelium," "sclera," and "optic nerve." PubMed search was conducted for papers published from January 2013 to October 2017. Inclusion criteria for papers were that they: (1) described the proteome of the human eye, (2) had tables, supporting data, and supplementary files that provided extensive protein lists, (3) used liquid chromatographytandemmass spectrometry (LC-MS/MS) to identify peptides and proteins. Exclusion criteria for papers were: (1) studies involving in vitro culture of human eye tissue cells, (2) studies using 2DE, since these provide limited coverage of the proteome, (3) studies that provided insufficient data on proteins that were identified. Data were extracted from supplementary files. The authoritative knowledge platform used for assigning UniProt numbers to individual proteins was NeXtProt (Swiss Institute of Bioinformatics). For those datasets that did not include UniProt numbers, protein accession numbers were converted to UniProt numbers by searching for the gene name against the UniProt database and confirming the entry based on protein name and in some cases, by online BLAST (National Library of Medicine, National Center for Biotechnology Information) searches of peptide sequences. Immunoglobulins and proteins with no "reviewed" UniProt number were excluded. Isoforms were not included unless the authors validated the isoform by peptide sequence. UniProt numbers for proteins newly discovered in each compartment of the eye were added to the existing database in a compartment-specific manner. ${ }^{[6]}$

\section{Proteomes of Human Eye Tissues and Fluids}

There has been considerable progress in characterizing the proteome of the various tissues of the human eye and its associated fluids since 2013. The biological samples, groups of subjects, sample processing, instrumentation, and criteria for peptide and protein identification in the 27 proteomic datasets of the human eye are summarized in Supporting Information, Table 1. The recent proteomic studies are highlighted below. We review advances in updating previously characterized proteomes of ocular compartments including tears, aqueous humor, lens, vitreous humor, retina, and retinal pigment epithelium (RPE)/ choroid and review data on previously uncharacterized proteomes including iris, ciliary body, sclera, and optic nerve. A complete list of nonredundant proteins found in each compartment and for the entire eye is reported in Supporting Information, Table 2. A summary of the total number of proteins in the different compartments is shown in Figure 1.

\subsection{Tears}

A thin layer of tear film protects and lubricates the ocular surface, providing oxygen and nutrients to underlying avascular tissues. The tear film is organized into an outer lipid layer, middle aqueous phase, and an inner glycocalyx or mucous layer that overlies the cornea and conjunctiva. ${ }^{[7]}$ Tears contain a variety of molecules including proteins and peptides, lipids, 
metabolites, and electrolytes in varying quantities. At the time of our review in 2013, the proteome of the human tear film had been well characterized in health ${ }^{[8-12]}$ and in diseases such as Sjogren's syndrome, ${ }^{[13]}$ dry eye syndrome (DES), blepharitis, ${ }^{[14]}$ keratoconus, ${ }^{[15-17]}$ thyroid eye disease, ${ }^{[18,19]}$ glaucoma ${ }^{[20,21]}$ and DR. ${ }^{[22]}$ An additional 128 proteins have been localized to the tear proteome since our review in 2013-although the apparent number has decreased from 1698 proteins to 1509 due to the exclusion of cDNA and immunoglobulins in the updated database. The proteome of human tears is of particular interest due to their ease of accessibility and the potential use of candidate proteins as biomarkers of ocular and systemic disease.

Since our 2013 review, the human tear proteome has been studied in DES and thyroidassociated orbitopathy (TAO). DES is an increasingly common, multifactorial pathology of the ocular surface that results in discomfort and in some cases decreased visual acuity. ${ }^{[23]} \mathrm{A}$ number of groups have investigated the tear proteome in patients with DES, ${ }^{\text {[13,24-29] }}$ demonstrating the downregulation of protective antibacterial proteins such as lacto-ferrin, lysozyme, and IgA-alpha compared with controls. ${ }^{[25,29]}$ Particular phenotypes of DES may be characterized by distinct alterations in protein expression. ${ }^{[30]}$ Perumal et al. explored the differences in proteomic profiles between patients with these three DES phenotypes compared with controls, employing label-free quantification. ${ }^{[31]}$ They identified 79 proteins that were differentially expressed in at least one DES subgroup compared to controls, 42 of which were novel protein associations with DES. Interestingly, low-abundance proteins were more likely to be differentially expressed between the three subtypes, demonstrating the importance of utilizing high-sensitivity MS techniques. A second study on patients with known TAO utilized Tandem Mass tag 6-plex experiments to identify 712 tear-associated proteins. Alpha-1 antichymotrypsin and cystatin c were found to be significantly upregulated and retinal dehydrogenase was significantly downregulated compared to controls. The authors suggested the use of these proteins as potential biomarkers in diagnosis of TAO, which frequently shares many common features with other diseases causing dry eye. ${ }^{[19]}$

\subsection{Cornea}

The cornea is a transparent, highly refractive and avascular tissue that consists of multiple layers with differing functions and properties. No additional studies of the cornea were identified since the time of our previous review in 2013. Prior to this, the cornea had been rather extensively studied in both health ${ }^{[32-34]}$ and in diseases such as Fuchs' dystrophy, $[35,36]$ keratoconus, ${ }^{[37]}$ lattice and granular corneal dystrophy. ${ }^{[38]}$

\subsection{Aqueous Humor}

The aqueous humor is a colorless, transparent medium that bathes the corneal endothelium, lens, and iris, with primary functions of maintaining intraocular pressure and nourishing the lens and cornea. It is also suspected to play a role in the immune response of the eye. ${ }^{[39]}$ The proteome of the aqueous humor is of particular interest in diseases of the anterior chamber but has the potential to be altered in any ocular disease. Prior to 2013, aqueous humor proteomics had been studied in healthy patients ${ }^{[40,41]}$ and in patients with acute corneal graft rejection, ${ }^{[42]}$ myopia, ${ }^{[43]}$ Fuchs' dystrophy, ${ }^{[44]}$ glaucoma, ${ }^{[45-50]}$ and AMD. ${ }^{[51]}$ The number of known proteins in the aqueous humor has nearly doubled, from 465 to 827 proteins, since 
our 2013 review was published. Aqueous humor proteins such as transforming growth factor (TGF)-beta 1 and ceruloplasmin could distinguish between eyes with AMD and healthy controls. ${ }^{[51]}$ A study that analyzed aqueous humor protein levels in patients following different types of glaucoma surgery found both a postoperative increase in overall protein concentration as well as differences in relative quantities of proteins depending on the type of surgery. ${ }^{[52]}$ It was postulated that differential changes in protein levels may explain the differences in risk of corneal decompensation following various glaucoma surgeries. ${ }^{[52]}$

Murthy et al. characterized the aqueous humor in 250 patients undergoing cataract surgery, identifying a total of 763 proteins, of which 386 were newly described for aqueous humor. Proteins they identified that had previously been identified included TGF-beta 2 and components of the complement pathway, which likely play a role in the immune response, angiogenic and anti-angiogenic proteins, and antioxidants such as glutathione and superoxide dismutase. The latter two classes of proteins are likely involved in maintaining corneal and lens clarity. They also identified sorbitol dehydrogenase (SORD), which functions to maintain lens clarity in the face of sorbitol, ${ }^{[53]}$ filensin (BFSP1) and phakinin (BFSP2), two cytoskeletal proteins, ${ }^{[54]}$ and various platelet-derived growth factors in the aqueous humor. Sorbitol dehydrogenase plays a role in the lens in converting sorbitol to fructose to allow diffusion out of the lens. Dysfunction of sorbitol dehydrogenase can lead to sorbitol collection in the lens and the development of diabetes-related cataract. BFSP1 and BFSP2 appear to be involved in lens fiber differentiation, and platelet derived growth factors are involved in angiogenesis and cell proliferation. High abundance proteins included enzymes involved in glycolysis, gluconeogenesis and pentose phosphate pathway, which most likely reflect the function of the aqueous to provide nourishment for the lens. ${ }^{[55]}$

\subsection{Iris}

The iris is a contractile tissue that forms the anterior most part of the uvea, with a primary purpose of regulating the amount of light entering the eye. The proteome of the iris is of particular interest due to its potential role in uveitis, or inflammation of the uvea, which is a common cause of decreased vision and blindness. ${ }^{[56]}$ The proteome of the iris was largely uncharacterized prior to 2013. Using LC-MS/MS on an Orbitrap Elite mass spectrometer, 2959 nonredundant proteins were identified in the iris of five healthy donors. Proteins found in the iris included myosins and tropomyosins related tomotor function, proteins related tomelanin pigmentation, collagens and matrix proteins and selenoproteins. ${ }^{[57]}$ The same year, Murthy et al. utilized an LTQ-Orbitrap Velosmass spectrometer to identify 4959 nonredundant proteins from healthy donor iris tissue. ${ }^{[58]}$ Overall, a total of 4232 proteins have been localized to the human iris to date. Iris proteins were involved in neuroprotection, membrane trafficking, maintenance of Golgi apparatus, biogenesis of melanosomes, and immune response.

\subsection{Ciliary Body}

The ciliary body is a muscular tissue located just posterior to the iris and is responsible for producing aqueous humor and changing the shape of the crystalline lens by controlling the zonules. The ciliary body is thought to play a key role in diseases such as primary open angle glaucoma and presbyopia. The proteome of the ciliary body was largely unstudied 
prior to 2013, with less than 50 proteins identified prior to that time. ${ }^{[59]}$ Since then, a total of 3371 proteins have been localized to the human ciliary body. Goel et al. identified 2815 proteins in the ciliary body, $95 \%$ of which had not previously been described in this tissue. Novel proteins identified included proteins in the vesicle mediated protein sorting family which play a role in recycling of membrane-associated proteins, desmin, which is associated with intermediate filament muscle fibers in cardiac, skeletal and smooth muscle, and exportins, which shuttle between the nucleus and the cytoplasm. Another study identified 2867 proteins in the ciliary body of five healthy donors, including four "missing proteins." The ciliary body contained many myosins, unconventional myosins, and tropomyosins which are related to ciliary muscle that controls the shape of the lens during accommodation. [57]

\subsection{Lens and Zonules}

The lens is a transparent structure composed primary of epithelial and fiber cells, with a high proportion of structural proteins called crystallins. ${ }^{[60]}$ Crystallins are known to be extremely long-lived proteins with very little turnover over time, making this an ideal tissue in which to study posttranslational modifications. ${ }^{[61]}$ It has been hypothesized that posttranslational modifications occurring over time may predispose to cataract formation. ${ }^{[61]}$ There has been a considerable increase in the number of known proteins in the human lens and zonule system from 273 in 2013 to 1117 known proteins to date. Mass spectrometry studies of the human lens prior to 2013 had identified deamidation, ${ }^{[62-64]}$ phosphorylation, ${ }^{[65,66]} \mathrm{S}$ methylation, and glycation ${ }^{[64]}$ as common posttranslational modifications of crystallins that occurred with increased aging and cataract formation. Wang et al. identified 951 proteins in the ocular lens of three human subjects using trypsin and pepsin digestion followed by HPLC-mass spectrometry-based multidimensional protein identification. In addition, 803 unique phosphorylation sites were identified on 264 proteins. Lens membrane contained a high amount of glycolysis/gluconeogenesis enzymes and proteins involved in cell-cell communication and signaling. Lens fibers contained a large amount of actin and proteins involved in glutathione metabolism. ${ }^{[67]}$

Zonules are a system of elastic radial fibers connecting the crystalline lens to the ciliary body, playing a key mechanical role in accommodation. ${ }^{[68]}$ The zonules weaken in normal aging and are pathologically affected in a number of eye diseases including exfoliation syndrome, Marfan syndrome, and homocystinuria. In 2017, De Maria et al. published the first proteomic exploration of the zonules in which they identified 144 proteins in human zonules, of which glycoproteins, primarily fibrillin (FBN1), and latent transforming growth factor beta binding protein 2 (LTBP2) were the most high-abundant proteins. Also notably present were signaling inhibitors, protease inhibitors, and cross-linking enzymes. ${ }^{\text {69] }}$

\subsection{Vitreous Humor}

The vitreous humor is a transparent medium that functions to maintain the shape of the eye and transport nutrients. Prior to 2013, the proteome of the vitreous had been studied in both health ${ }^{[70-72]}$ and in diseases such as DR. ${ }^{[73,74]}$ Since that time, seven new studies have been published outlining the proteome in human vitreous in healthy eyes ${ }^{[75-77]}$ and several diseases including DR, ${ }^{[78]}$ retinoblastoma, ${ }^{[79]}$ retinal vein occlusion, ${ }^{[80]}$ and glaucoma[81], 
with the number of known vitreous humor proteins increasing nearly 12 -fold from 545 to 6538. In patients with varying stages of DR, 2482 proteins were identified of which 230 were found to be higher in proliferative retinopathy rather than the nonproliferative phenotype. This group also showed downregulation of 72 proteins posttreatment with intravitreal antibodies against vascular endothelial growth factor. ${ }^{[78]}$ Another group conducted iTRAQ-coupled ESI-MS/MS technology to analyze vitreous humor in patients with retinoblastoma, finding several proteins to be highly dysregulated including matrix metalloproteinase 2 (MMP2), tenascin C (TNC), CD44, polycomb protein SUZ12 (SUZ12), and cellular retinoic acid binding protein 1 (CRABP1) ${ }^{\left[{ }^{79]}\right.}$ Subjects with glaucoma were found to have significant downregulation of crystallins (which have also been implicated in neuroprotection), antioxidant proteins, and upregulation of the complement cascade, however it remains unclear if these alterations have clinical significance or simply reflect efflux of proteins from the retina. ${ }^{[81]}$

As demonstrated by Skeie and colleagues, while the primary function of the vitreous is thought to be structural, proteomic studies indicate the presence of proteins involved in immune functions, oxidative stress regulation, and energy metabolism, making the vitreous potentially more biologically active than previously believed. ${ }^{[77]}$ Extracellular matrix proteins and complement factors are differentially expressed in the vitreous. ${ }^{[77]}$

\subsection{Retina}

The retina consists of multiple layers of neuronal cells with an underlying retinal pigment epithelium, with a primary function of converting light into neural signals to be processed by the brain. AMD and DR are the most common retinal diseases that cause decreased vision and blindness. Prior to 2013, the retinal proteome had been studied in both health and disease, ${ }^{[82-86]}$ and since that time over 4000 proteins have been added to the retinal proteome, increasing the total number of known proteins to 4832. Proteins in the healthy human retina primarily include enzymes involved in the visual cycle and retinoid metabolism. ${ }^{\left[{ }^{[7]}\right.}$ More recently, the retinal proteome has been studied in ocular hypertension, ${ }^{[88]}$ glaucoma, ${ }^{[81,89]} \mathrm{X}$-linked retinoschisis. ${ }^{[90]}$ Funke et al. showed alterations in proteins related to cellular development, stress, and cell death in glaucomatous retinas compared to healthy controls. ${ }^{[89]}$ Although ocular hypertensive retinas did not show evidence of cell death or neuroinflammation, they had downregulated mitochondrial oxidative phosphorylation proteins (possibly signifying metabolic failure), and upregulation of DNA repair enzymes and ubiquitin proteasome pathway components. ${ }^{[8]}$

\subsection{Choroid/RPE complex}

The choroid is a network of blood vessels that provides nourishment to the outer retina and RPE. The RPE is a layer of cuboidal epithelial cells lining the posterior aspect of the retina that plays a role in recycling photoreceptors and reducing light scatter. Due to technical difficulties in separating the RPE and choroid, they are typically studied in conjunction, termed the choroid/RPE "complex." [91] Since 2013, the number of known proteins in the human RPE/choroid complex has increased from 897 to 6049. Skeie et al. identified 4403 unique proteins in the foveal, macular, and peripheral choroid-RPE tissues using multidimensional LC-MS/MS. Proteins with highest expression in the fovea and macular 
region included inflammation-related proteins such as human leukocyte antigen (HLA)-A, HLA-B, HLA-C, and complement factors. Proteins with higher expression in the periphery included bestrophin and complement inhibitor CD55. ${ }^{[92]}$ Dammali et al. identified 5309 unique proteins in the human RPE/choroid complex. ${ }^{[93]}$

\subsection{Optic Nerve}

The optic nerve is a white matter tract that is formed by retinal ganglion cell axons in the retina, conveying visual information to the brain. ${ }^{[94]}$ The proteome of the optic nerve is of particular interest due to its role in common diseases such as glaucoma and optic neuritis. Prior to 2013, the proteome of the optic nerve was not well characterized, with one study showing elevated peptidyl arginine deiminase 2 and citrillunated myelin basic protein in primary open angle glaucoma. ${ }^{[95]}$ Proteomic analysis of optic nerve from five healthy adults using LC-MS/MS on an Orbitrap Elite mass spectrometer showed over 2000 proteins in the retrobulbar optic nerve. These proteins included astrocytic proteins (glial fibrillary acidic protein and aquaporin-4), oligodendrocytic proteins (laminin, proteolipid protein, and fibronectin) as well as myelin proteins (myelin basic protein, myelin-associated glycoprotein), paranodal structural proteins, and cytoskeletal proteins. ${ }^{[96]}$ To date, there are 2670 known proteins in the human optic nerve.

\subsection{Sclera}

The sclera is a dense, irregular connective tissue that forms the outer surface of the eye, ${ }^{\text {[97] }}$ with a primary role of protection of the ocular contents and maintenance of the shape of the eye. The proteome of the sclera has not been well-characterized but is of interest due to its potential role in myopia, which is growing in prevalence at epidemic proportions. ${ }^{[98]} \mathrm{In}$ addition, the sclera is home to Schlemm's canal which is implicated in glaucoma pathogenesis. The sclera was studied in conjunction with the optic nerve by Zhang et al., identifying 1895 nonredundant proteins after excluding immunoglobulins. The major proteins in the sclera were found to be collagens, including 18 different collagen chains. ${ }^{[96]}$ Noncollagenous extracellular matrix proteins included proteoglycans such as decorin and fibromodulin, glycoproteins such as fibronectin and laminin, matrix metalloproteinases, and integrins which may be implicated in the development of myopia. ${ }^{[99]}$

\section{Missing Proteins}

Missing proteins are those belonging to predicted protein-coding genes that have evidence for existence but have not yet been characterized on the protein level. ${ }^{[100]}$ It is thought that missing proteins might be expressed significantly only in under-researched organs, ${ }^{[101]}$ highlighting the potential importance of a continued search for these missing proteins within the eye and associated biofluids. The Human Proteome Project (HPP) has established guidelines for high-quality detection of the 1482 missing proteins, including using (1) a $1 \%$ protein $\mathrm{FDR}^{[102]}$ (2) two uniquely mapping nonnested peptides with a minimum length of nine amino acids and making the spectra publically available, and (3) including all potential protein sequences in the search criteria instead of only searching missing protein databases. ${ }^{[103]}$ Zhang et al. described four missing proteins in the iris based upon a $1 \%$ protein FDR, length > nine amino acids, and publication of the spectra. ${ }^{[57]}$ In other studies, claims were 
made for finding sixteen missing proteins in iris, ${ }^{[58]}$ and two missing proteins in the choroid/RPE complex, ${ }^{[93]}$ but the level of evidence fails to reach the high-quality guidelines of the HPP.

\section{Recommendations and Future Directions}

As evident in Supporting Information, Table 1, investigators have used a wide range of criteria to process mass spectrometry data, some using relatively high protein FDR and scant details regarding minimum peptide length, and number of peptides for protein identification. Manual verification of isoforms was not done in nearly all the studies. For future studies of the human eye proteome, we suggest that papers conform to high-quality guidelines of the HPP and Minimum Information About a Proteomics Experiment (MIAPE) ${ }^{[104,105]}$ with additional suggestions in Table 1. Following the publication of our initial compilation of proteins identified in the EyeOme in 2013, the importance of more rigorous standards for protein identification was underscored. ${ }^{[105]}$ Since that time, there has been considerable progress including increasingly common use of matching based on two peptides and use of lower FDR's. The adherence to more stringent criteria is imperative to achieve the goal of the HUPO Biology and Disease-driven Human Proteome Project which is to improve understanding of the pathophysiology of eye disease and to spearhead the formation of new preventative and therapeutic modalities.

\section{Supplementary Material}

Refer to Web version on PubMed Central for supplementary material.

\section{Acknowledgments}

This study was supported by the National Institutes of Health R01 AG27012, R01 EY024596, the Edward N. and Della L. Thome Memorial Foundation, and the Intramural Branch of the National Institute on Aging, Baltimore, Maryland.

\section{Abbreviations}

AMD

DES

DR

RPE

TGF-beta 1 age-related macular degeneration

dry eye syndrome

diabetic retinopathy

retinal pigment epithelium

transforming growth factor-beta 1

\section{References}

1. Bourne RRA, Flaxman SR, Braithwaite T, Cicinelli MV, Das A, Jonas JB, Keeffe J, Kempen JH, Leasher J, Limburg H, Naidoo K, Pesudovs K, Resnikoff S, Silvester A, Stevens GA, Tahhan N, Wong TY, Taylor HR. Lancet Glob Heal. 2017; 5:e888.

2. Gordois A, Cutler H, Pezzullo L, Gordon K, Cruess A, Winyard S, Hamilton W, Chua K. Glob Public Health. 2012; 7:465. [PubMed: 22136197]

3. Global Data on Visual Impairments 2010. World Health Organization; 2012. p. 114 
4. Zhang M, Luo H, Xi Z, Rogaeva E. PLoS One. 2015; 10:e0126082. [PubMed: 25946000]

5. Velez G, Roybal CN, Colgan D, Tsang SH, Bassuk AG, Mahajan VB. JAMA Ophthalmol. 2016; 134:444. [PubMed: 26848019]

6. Semba RD, Enghild JJ, Venkatraman V, Dyrlund TF, Van Eyk JE. Proteomics. 2013; 13:2500. [PubMed: 23749747]

7. Green-Church KB, Butovich I, Willcox M, Borchman D, Paulsen F, Barabino S, Glasgow BJ. Investig Ophthalmol Vis Sci. 2011; 52:1979. [PubMed: 21450916]

8. Green-Church KB, Nichols KK, Kleinholz NM, Zhang L, Nichols JJ. Mol Vis. 2008; 14:456. [PubMed: 18334958]

9. Zhou L, Zhao SZ, Koh SK, Chen L, Vaz C, Tanavde V, Li XR, Beuerman RW. J Proteomics. 2012; 75:3877. [PubMed: 22634083]

10. Gonzalez N, Iloro I, Duran JA, Elortza F, Suarez T. Mol Vis. 2012; 18:1572. [PubMed: 22736947]

11. Li N, Wang N, Zheng J, Liu XM, Lever OW, Erickson PM, Li L. J Proteome Res. 2005; 4:2052. [PubMed: 16335950]

12. de Souza GA, Godoy LMF, Mann M. Genome Biol. 2006; 7:R72. [PubMed: 16901338]

13. Tomosugi N, Kitagawa K, Takahashi N, Sugai S, Ishikawat I. J Proteome Res. 2005; 4:820. [PubMed: 15952728]

14. Koo BS, Lee DY, Ha HS, Kim JC, Kim CW. J Proteome Res. 2005; 4:719. [PubMed: 15952718]

15. Lema I, Brea D, Rodríguez-González R, Díez-Feijoo E, Sobrino T. Mol Vis. 2010; 16:2055. [PubMed: 21042560]

16. Pannebaker C, Chandler HL, Nichols JJ. Mol Vis. 2010; 16:1949. [PubMed: 21031023]

17. Acera A, Vecino E, Rodríguez-Agirretxe I, Aloria K, Arizmendi JM, Morales C, Durán JA. Eye. 2011; 25:1225. [PubMed: 21701529]

18. Okrojek R, Grus FH, Matheis N, Kahaly GJ. Horm Metab Res. 2009; 41:465. [PubMed: 19373747]

19. Kishazi E, Dor M, Eperon S, Oberic A, Hamedani M, Turck N. J Proteomics. 2018; 170:110. [PubMed: 28887209]

20. Pieragostino D, Bucci S, Agnifili L, Fasanella V, D'Aguanno S, Mastropasqua A, Ciancaglini M, Mastropasqua L, Di Ilio C, Sacchetta P, Urbani A, Del Boccio P. Mol Biosyst. 2012; 8:1017. [PubMed: 22124706]

21. Wong TT, Zhou L, Li J, Tong L, Zhao SZ, Li XR, Yu SJ, Koh SK, Beuerman RW. Investig Ophthalmol Vis Sci. 2011; 52:7385. [PubMed: 21697136]

22. Csosz E, Boross PP, Csutak A, Berta AA, Toth F, Poliska S, Torok Z, Tozser J, Csõsz É, Boross PP, Csutak A, Berta AA, Tóth F, Póliska S, Török Z, Tõzsér J. J Proteomics. 2012; 75:2196. [PubMed: 22300579]

23. International Dry Eye Workshop. Ocul Surf. 2007; 5:93. [PubMed: 17508117]

24. Grus FH, Podust VN, Bruns K, Lackner K, Fu S, Dalmasso EA, Wirthlin A, Pfeiffer N. Investig Ophthalmol Vis Sci. 2005; 46:863. [PubMed: 15728542]

25. Zhou L, Beuerman RW, Chan CM, Zhao SZ, Li XR, Yang H, Tong L, Liu S, Stern ME, Tan D. J Proteome Res. 2009; 8:4889. [PubMed: 19705875]

26. Versura P, Nanni P, Bavelloni A, Blalock WL, Piazzi M, Roda A, Campos EC. Eye. 2010; 24:1396. [PubMed: 20150925]

27. Tong L, Zhou L, Beuerman RW, Zhao SZ, Li XR. Br J Ophthalmol. 2011; 95:848. [PubMed: 21030416]

28. Cojocaru VM, Ciurtin C, Uyy E, Antohe FA. Dig J Nanomater Biostructures. 2011; 6:507.

29. Srinivasan S, Thangavelu M, Zhang L, Green KB, Nichols KK. Investig Ophthalmol Vis Sci. 2012; 53:5052. [PubMed: 22736608]

30. Boehm N, Funke S, Wiegand M, Wehrwein N, Pfeiffer N, Grus FH. Investig Ophthalmol Vis Sci. 2013; 54:2385. [PubMed: 23425692]

31. Perumal N, Funke S, Pfeiffer N, Grus FH. Sci Rep. 2016; 6:29629. [PubMed: 27436115]

32. Karring H, Thogersen IB, Klintworth GK, Moller-Pedersen T, Enghild JJ. Mol Cell Proteomics. 2005; 4:1406. [PubMed: 15911533] 
33. Galiacy SD, Froment C, Mouton-Barbosa E, Erraud A, Chaoui K, Desjardins L, Monsarrat B, Malecaze F, Burlet-Schiltz O. J Proteomics. 2011; 75:81. [PubMed: 21989269]

34. Dyrlund TF, Poulsen ET, Scavenius C, Nikolajsen CL, Thogersen IB, Vorum H, Enghild JJ. J Proteome Res. 2012; 11:4231. [PubMed: 22698189]

35. Jurkunas UV, Rawe I, Bitar MS, Zhu C, Harris DL, Colby K, Joyce NC. Investig Opthalmology Vis Sci. 2008; 49:2956.

36. Jurkunas UV, Bitar M, Rawe I. Investig Opthalmology Vis Sci. 2009; 50:1129.

37. Nielsen K, Vorum H, Fagerholm P, Birkenkamp-Demtröder K, Honoré B, Ehlers N, Orntoft TF. Exp Eye Res. 2006; 82:201. [PubMed: 16083875]

38. Karring H, Runager K, Thogersen IB, Klintworth GK, Hojrup P, Enghild JJ. Exp Eye Res. 2012; 96:163. [PubMed: 22155582]

39. Kramer M, Goldenberg-Cohen N, Axer-Siegel R, Weinberger D, Cohen Y, Monselise Y. Ocul Immunol Inflamm. 2005; 13:305. [PubMed: 16159722]

40. Chowdhury UR, Madden BJ, Charlesworth MC, Fautsch MP. Invest Ophthalmol Vis Sci. 2010; 51:4921. [PubMed: 20463327]

41. Richardson MR, Price MO, Price FW, Pardo JC, Grandin JC, You J, Wang M, Yoder MC. Mol Vis. 2009; 15:2740. [PubMed: 20019884]

42. Funding M, Vorum H, Honoré B, Nexo E, Ehlers N. Acta Ophthalmol Scand. 2005; 83:31. [PubMed: 15715554]

43. Duan X, Lu Q, Xue P, Zhang H, Dong Z, Yang F, Wang N. Mol Vis. 2008; 14:370. [PubMed: 18334949]

44. Richardson MR, Segu ZM, Price MO, Lai X, Witzmann FA, Mechref Y, Yoder MC, Price FW. Mol Vis. 2010; 16:2376. [PubMed: 21139973]

45. Grus FH, Joachim SC, Sandmann S, Thiel U, Bruns K, Lackner KJ, Pfeiffer N. Mol Vis. 2008; 14:1437. [PubMed: 18682810]

46. Duan X, Xue P, Wang N, Dong Z, Lu Q, Yang F. Mol Vis. 2010; 16:2839. [PubMed: 21203405]

47. Izzotti A, Longobardi M, Cartiglia C, Sacca SC. J Proteome Res. 2010; 9:4831. [PubMed: 20666514]

48. Anshu A, Price MO, Richardson MR, Segu ZM, Lai X, Yoder MC, Price FW. Mol Vis. 2011; 17:1891. [PubMed: 21850163]

49. Saccá SC, Centofanti M, Izzotti A. Investig Ophthalmol Vis Sci. 2012; 53:4242. [PubMed: 22618596]

50. Bouhenni RA, Al Shahwan S, Morales J, Wakim BT, Chomyk AM, Alkuraya FS, Edward DP. Exp Eye Res. 2011; 92:67. [PubMed: 21078314]

51. Kim TW, Kang JW, Ahn J, Lee EK, Cho KC, Han BNR, Hong NY, Park J, Kim KP. J Proteome Res. 2012; 11:4034. [PubMed: 22702841]

52. Rosenfeld C, Price MO, Lai X, Witzmann FA, Price FW Jr. Mol Vis. 2015; 21:911. [PubMed: 26321865]

53. Chan AWH, Ho Y, Chung SK, Chung SSM. Exp Eye Res. 2008; 87:454. [PubMed: 18760274]

54. Jakobs PM, Hess JF, FitzGerald PG, Kramer P, Weleber RG, Litt M. Am J Hum Genet. 2000; 66:1432. [PubMed: 10739768]

55. Murthy KR, Rajagopalan P, Pinto SM, Advani J, Murthy PR, Goel R, Subbannayya Y, Balakrishnan L, Dash M, Anil AK, Manda SS, Nirujogi RS, Kelkar DS, Sathe GJ, Dey G, Chatterjee A, Gowda H, Chakravarti S, Shankar S, Sahasrabuddhe NA, Nair B, Somani BL, Prasad TS, Pandey A. OMICS. 2015; 19:283. [PubMed: 25933257]

56. Miserocchi E, Fogliato G, Modorati G, Bandello F. Eur J Ophthalmol. 2013; 23:705. [PubMed: 23661536]

57. Zhang P, Kirby D, Dufresne C, Chen Y, Turner R, Ferri S, Edward DP, Van Eyk JE, Semba RD. Proteomics. 2016; 16:1146. [PubMed: 26834087]

58. Murthy KR, Dammalli M, Pinto SM, Murthy KB, Nirujogi RS, Madugundu AK, Dey G, Subbannayya Y, Mishra UK, Nair B, Gowda H, Prasad TSK. Omi J Integr Biol. 2016; 20:510. 
59. Goel R, Murthy KR, Srikanth SM, Pinto SM, Bhattacharjee M, Kelkar DS, Madugundu AK, Dey G, Mohan SS, Krishna V, Prasad TK, Chakravarti S, Harsha H, Pandey A. Clin Proteomics. 2013; 10:9. [PubMed: 23914977]

60. Zhang C, Liu P, Wang N, Li Y, Wang L. Mol Vis. 2007; 13:1873. [PubMed: 17960125]

61. Kyselova Z. Mass Spectrom Rev. 2011; 30:1173. [PubMed: 22031278]

62. Hains PG, Truscott RJW. Investig Ophthalmol Vis Sci. 2010; 51:3107. [PubMed: 20053973]

63. Hains PG, Truscott RJW. Proteomics - Clin Appl. 2008; 2:1611. [PubMed: 21136811]

64. Wilmarth PA, Tanner S, Dasari S, Nagalla SR, Riviere MA, Bafha V, Pevzner PA, David LL. J Proteome Res. 2006; 5:2554. [PubMed: 17022627]

65. Huang CH, Wang YT, Tsai CF, Chen YJ, Lee JS, Chiou SH. Mol Vis. 2011; 17:186. [PubMed: 21264232]

66. MacCoss MJ, McDonald WH, Saraf A, Sadygov R, Clark JM, Tasto JJ, Gould KL, Wolters D, Washburn M, Weiss A, Clark JI, Yates JR. Proc Natl Acad Sci U S A. 2002; 99:7900. [PubMed: 12060738]

67. Wang Z, Han J, David LL, Schey KL. Invest Ophthalmol Vis Sci. 2013; 54:1135. [PubMed: 23349431]

68. Raviola G. Invest Ophthalmol. 1971; 10:851. [PubMed: 4107306]

69. De Maria A, Wilmarth PA, David LL, Bassnett S. Investig Opthalmology Vis Sci. 2017; 58:573.

70. Koyama R, Nakanishi T, Ikeda T, Shimizu A. J Chromatogr B Anal Technol Biomed Life Sci. 2003; 792:5.

71. Yamane K, Minamoto A, Yamashita H, Takamura H, Miyamoto-Myoken Y, Yoshizato K, Nabetani T, Tsugita A, Mishima HK. Mol Cell Proteomics. 2003; 2:1177. [PubMed: 12975481]

72. Shitama T, Hayashi H, Noge S, Uchio E, Oshima K, Haniu H, Takemori N, Komori N, Matsumoto H. Proteomics - Clin Appl. 2008; 2:1265. [PubMed: 19081814]

73. Kim T, Sang JK, Kim K, Kang UB, Lee C, Kyong SP, Hyeong GY, Kim Y. Proteomics. 2007; 7:4203. [PubMed: 17955474]

74. Gao BB, Chen X, Timothy N, Aiello LP, Feener EP. J Proteome Res. 2008; 7:2516. [PubMed: 18433156]

75. Murthy KR, Goel R, Subbannayya Y, Jacob HK, Murthy PR, Manda S, Patil AH, Sharma R, Sahasrabuddhe NA, Parashar A, Nair BG, Krishna V, Prasad T, Gowda H, Pandey A. Clin Proteomics. 2014; 11:29. [PubMed: 25097467]

76. Yee KMP, Feener EP, Madigan M, Jackson NJ, Gao BB, Ross-Cisneros FN, Provis J, Aiello LP, Sadun AA, Sebag J. Investig Ophthalmol Vis Sci. 2015; 56:7036. [PubMed: 26529037]

77. Skeie JM, Roybal CN, Mahajan VB. PLoS One. 2015; 10

78. Loukovaara S, Nurkkala H, Tamene F, Gucciardo E, Liu X, Repo P, Lehti K, Varjosalo M. J Proteome Res. 2015; 14:5131. [PubMed: 26490944]

79. Naru J, Aggarwal R, Singh U, Mohanty AK, Bansal D, Mangat N, Kakkar N, Agnihotri N. Tumor Biol. 2016; 37:13915.

80. Reich M, Dacheva I, Nobl M, Siwy J, Schanstra JP, Mullen W, Koch FHJ, Kopitz J, Kretz FTA, Auffarth GU, Koss MJ. PLoS One. 2016; 11:e0158001. [PubMed: 27362861]

81. Mirzaei M, Gupta VB, Chick JM, Greco TM, Wu Y, Chitranshi N, Vander Wall R, Hone E, Deng L, Dheer Y, Abbasi M, Rezaeian M, Braidy N, You Y, Salekdeh GH, Haynes PA, Molloy MP, Martins R, Cristea IM, Gygi SP, Graham SL, Gupta VK. Sci Rep. 2017; 7:12685. [PubMed: 28978942]

82. Ethen CM, Reilly C, Feng X, Olsen TW, Ferrington DA. Investig Ophthalmol Vis Sci. 2006; 47:2280. [PubMed: 16723435]

83. Crabb JW, Miyagi M, Gu X, Shadrach K, West KA, Sakaguchi H, Kamei M, Hasan A, Yan L, Rayborn ME, Salomon RG, Hollyfield JG. Proc Natl Acad Sci U S A. 2002; 99:14682. [PubMed: 12391305]

84. Len ACL, Powner MB, Zhu L, Hageman GS, Song X, Fruttiger M, Gillies MC. J Proteome Res. 2012; 11:537. [PubMed: 22098468]

85. Wang H, Feng L, Hu J, Xie C, Wang F. Proteome Sci. 2012; 10:15. [PubMed: 22390717] 
86. Decanini A, Karunadharma PR, Nordgaard CL, Feng X, Olsen TW, Ferrington DA. Diabetologia. 2008; 51:1051. [PubMed: 18414830]

87. Zhang P, Dufresne C, Turner R, Ferri S, Venkatraman V, Karani R, Lutty GA, Van Eyk JE, Semba RD. Proteomics. 2015; 15:836. [PubMed: 25407473]

88. Yang X, Hondur G, Li M, Cai J, Klein JB, Kuehn MH, Tezel G. Investig Ophthalmol Vis Sci. 2015; 56:5816. [PubMed: 26348630]

89. Funke S, Perumal N, Beck S, Gabel-Scheurich S, Schmelter C, Teister J, Gerbig C, Gramlich OW, Pfeiffer N, Grus FH. Sci Rep. 2016; 6:29759. [PubMed: 27425789]

90. Sudha D, Kohansal-Nodehi M, Kovuri P, Manda SS, Neriyanuri S, Gopal L, Bhende P, Chidambaram S, Arunachalam JP. Clin Proteomics. 2017; 14:13. [PubMed: 28450823]

91. Hathout Y, Flippin J, Fan C, Liu P, Csaky K. J Proteome Res. 2005; 4:620. [PubMed: 15822943]

92. Skeie JM, Mahajan VB. JAMA Ophthalmol. 2014; 132:1271. [PubMed: 25058583]

93. Dammalli M, Murthy KR, Pinto SM, Murthy KB, Nirujogi RS, Madugundu AK, Dey G, Nair B, Gowda H, Keshava Prasad TS. OMICS. 2017; 21:114. [PubMed: 28186866]

94. Yanoff, M., Sassani, JW. Ocular Pathology. 7. Elsevier; 2015. p. 441

95. Bhattacharya SK, Crabb JS, Bonilha VL, Gu X, Takahara H, Crabb JW. Investig Ophthalmol Vis Sci. 2006; 47:2508. [PubMed: 16723463]

96. Zhang P, Karani R, Turner RL, Dufresne C, Ferri S, Van Eyk JE, Semba RD. Proteomics. 2016; 16:2592. [PubMed: 27538499]

97. Harper AR, Summers JA. Exp Eye Res. 2015; 133:100. [PubMed: 25819458]

98. Dolgin E. Nature. 2015; 519:276. [PubMed: 25788077]

99. McBrien NA, Metlapally R, Jobling AI, Gentle A. Investig Ophthalmol Vis Sci. 2006; 47:4674. [PubMed: 17065473]

100. Gaudet P, Argoud-Puy G, Cusin I, Duek P, Evalet O, Gateau A, Gleizes A, Pereira M, Zahn-Zabal M, Zwahlen C, Bairoch A, Lane L. J Proteome Res. 2013; 12:293. [PubMed: 23205526]

101. Lane L, Bairoch A, Beavis RC, Deutsch EW, Gaudet P, Lundberg E, Omenn GS. J Proteome Res. 2014; 13:15. [PubMed: 24364385]

102. Omenn GS, Lane L, Lundberg EK, Beavis RC, Nesvizhskii AI, Deutsch EW. J Proteome Res. 2015; 14:3452. [PubMed: 26155816]

103. Omenn GS, Lane L, Lundberg EK, Overall CM, Deutsch EW. J Proteome Res. 2017; doi: 10.1021/acs.jproteome.7b00375

104. Binz PA, Barkovich R, Beavis RC, Creasy D, Horn DM, Julian RK Jr, Seymour SL, Taylor CF, Vandenbrouck Y. Nat Biotechnol. 2008; 26:862. [PubMed: 18688233]

105. Omenn GS. Proteomics. 2013; 13:2375. [PubMed: 23852748] 


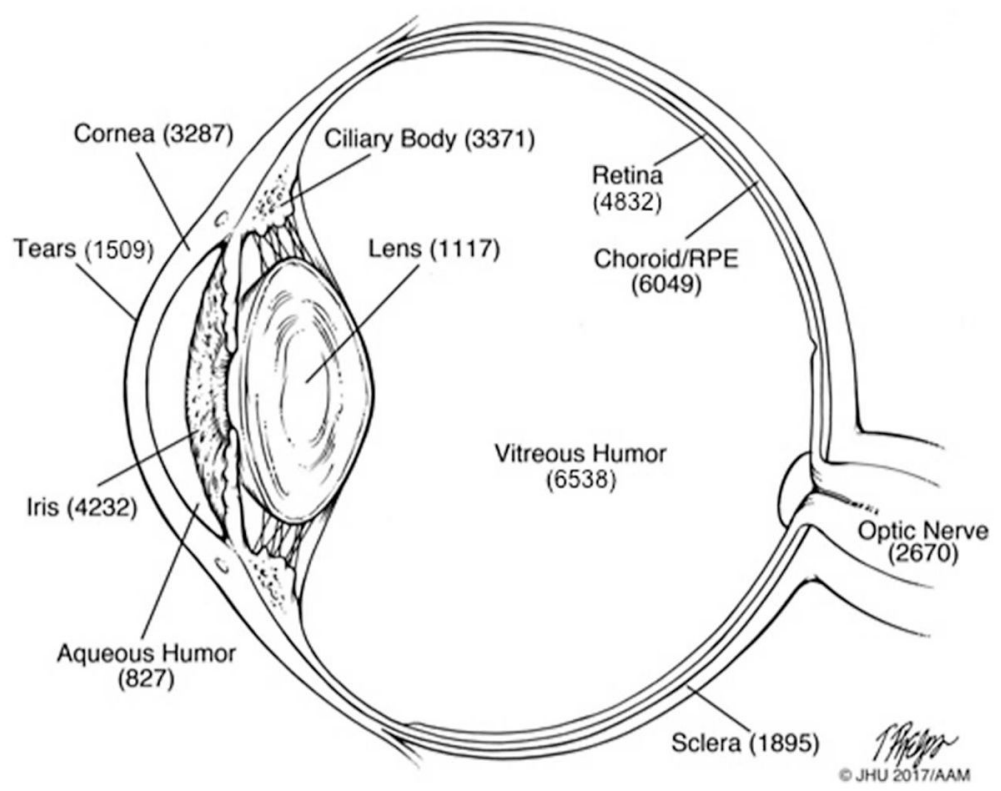

Figure 1.

Schematic diagram of the human eye with the number of nonredundant proteins identified in various tissues and biofluids. 


\section{Table 1}

General recommendations for generating high-confidence proteomic datasets on the human eye.

\begin{tabular}{|c|c|}
\hline \multicolumn{2}{|c|}{ Recommendations } \\
\hline Samples & At least three biological replicates \\
\hline \multirow[t]{3}{*}{ Peptides } & $\geq 7$ amino acids minimum peptide length \\
\hline & - $\quad$ Minimum of two peptide match \\
\hline & - $\quad$ One peptide match if MS2 spectra manually inspected \\
\hline \multirow[t]{3}{*}{ False discovery rate } & Peptide FDR cutoff $₫) .1 \%$ \\
\hline & - $\quad$ Protein FDR cutoff $\unlhd \%$ \\
\hline & - $\quad$ Both protein and peptide FDR must be clearly stated in Methods \\
\hline \multirow[t]{2}{*}{ Protein identifiers } & $\begin{array}{l}\text { - NeXtProt accession should be utilized along with protein name on NeXtProt, with other synonyms } \\
\text { removed }\end{array}$ \\
\hline & - $\quad$ Peptide sequences used to identify the protein should be included in Supporting Information \\
\hline Protein isoforms & $\begin{array}{l}\text { - Manual verification including comparing peptide amino acid sequences compared with sequence } \\
\text { alignment of the different isoforms and verification of spectra manually }\end{array}$ \\
\hline \multirow[t]{2}{*}{ Missing proteins } & Follow HUPO expert committee guidelines ${ }^{[101]}$ \\
\hline & - $\quad$ Provide MS2 spectra in supplementary material \\
\hline Mass spectrometry data & $\begin{array}{l}\text { - } \quad \text { MS data should be deposited in ProteomeXchange for inspection and use by the proteomics } \\
\text { community }\end{array}$ \\
\hline
\end{tabular}

